\title{
Retraction: Overexpression of HDAC8 and down-regulation of CDKN2A is associated with worse prognosis of esophageal squamous cell carcinoma
}

\author{
Effat Un Nesa ${ }^{1}$, Xuan Chen ${ }^{1}$, Cong Wang ${ }^{1}$, Xue Chen ${ }^{1}$, Yuan Wang ${ }^{2}$, Yan $\mathbf{Q u}^{1}$, Si Mi ${ }^{1}$, Shanghai Guan ${ }^{1}$, \\ Fengxia Xiao', Yufeng Cheng ${ }^{1}$ \\ ${ }^{1}$ Department of Radiation Oncology, Qilu Hospital of Shandong University, Ji'nan 250012, China; ${ }^{2}$ Department of Radiation Oncology, Linyi \\ People's Hospital, Linyi 276003, China \\ Correspondence to: Yufeng Cheng. Department of Radiation oncology, Qilu Hospital of Shandong University, Ji'nan 250012, China. \\ Email: qlyufengcheng@126.com.
}

Submitted Jun 10, 2021. Accepted for publication Jun 21, 2021.

doi: $10.21037 /$ tcr-21-1136

View this article at: https://dx.doi.org/10.21037/tcr-21-1136

Retraction to: Transl Cancer Res 2020;9:1406-17

The article "Overexpression of HDAC8 and down-regulation of CDKN2A is associated with worse prognosis of esophageal squamous cell carcinoma" (doi: 10.21037/tcr.2020.01.32) published in the Volume 9 No. 3 (March 2020) issue of Translational Cancer Research has been retracted at the request by all the authors as some obvious errors in statistical analysis and graph were found. We apologize for the inconvenience caused.

\section{Footnote}

Conflicts of Interest: All authors have completed the ICMJE uniform disclosure form (available at https://dx.doi.org/10.21037/ tcr-21-1136). The authors have no conflicts of interest to declare.

Ethical Statement: The authors are accountable for all aspects of the work in ensuring that questions related to the accuracy or integrity of any part of the work are appropriately investigated and resolved.

Open Access Statement: This is an Open Access article distributed in accordance with the Creative Commons AttributionNonCommercial-NoDerivs 4.0 International License (CC BY-NC-ND 4.0), which permits the non-commercial replication and distribution of the article with the strict proviso that no changes or edits are made and the original work is properly cited (including links to both the formal publication through the relevant DOI and the license). See: https://creativecommons.org/ licenses/by-nc-nd/4.0/.

Cite this article as: Nesa EU, Chen X, Wang C, Chen X, Wang Y, Qu Y, Mi S, Guan S, Xiao F, Cheng Y. Retraction: Overexpression of HDAC8 and down-regulation of CDKN2A is associated with worse prognosis of esophageal squamous cell carcinoma. Transl Cancer Res 2021;10(7):3605. doi: 10.21037/ tcr-21-1136 